\title{
Airborne Pollen Records of Shomolu Local Government Area in Lagos State
}

\author{
Tiwalade Adeyemi ADENIYI ${ }^{1 *}$, Peter A. ADEONIPEKUN ${ }^{1}$, \\ James D. OLOWOKUDEJO ${ }^{1}$, Idowu S. AKANDE ${ }^{2}$ \\ IDepartment of Botany, Faculty of Science,University ofLagos, Nigeria; dessytwa@yahoo.com (*corresponding author); jolowokudejo@unilag.edu.ng \\ pladeonipekun@yahoo.com \\ 2Department of Biochemistry, Faculty of Science, University of Lagos, Nigeria; iakande@unilag.edu.ng;
}

\begin{abstract}
Data on the prevalence of pollen in the atmosphere is limited and almost non-existent for Lagos State and Nigeria. Pollen grains are known to be highly allergenic and thus they are potential causes of respiratory diseases. To investigate airborne incidence of pollen, so as to construct a pollen calendar and contribute to current trends in the development of aeropalynology/allergy study in Nigeria, three highly populated locations in Shomolu Local Government areas of Lagos State: University of Lagos, Bariga and Gbagada, were sampled. Aero-samplers were harvested monthly from January 2013 to December 2013. After acetolysis treatment and analysis, the total pollen count was 4393, belonging to 38 pollen taxa and 29 families. The main taxa include Poaceae, Cyperaceae, Amaranthaceae, Ludwigia and Alchornea. Monthly pollen counts were highest in October and lowest in June. Almost three-quarters of the total pollen content came from grasses and weeds. This composition reflects the ornamental and grassland flora of the town, as well as the natural vegetation surrounding the urban area. The total pollen concentration correlates positively with the temperature and negatively with the wind, rainfall and relative humidity, which was similar in the dominant taxa Amaranthaceae and Alchornea. Dominant taxa Cyperaceae and Ludwigia have significant positive correlation with wheezing cough. Results from this work will form the basis for a forecast service required to inform and educate the general public and allergy sufferers about pollen distribution in Lagos State.
\end{abstract}

Keywords: aeropalynology, allergy, pollen grain, respiratory diseases

\section{Introduction}

Unlike other parts of the world (Moreno-Grau et al., 2000; Adler et al., 1985; Dola et al., 2004) where extensive research has been carried out on aeropalynology and its role in allergies, Africa is totally lacking this sort of data. Apart from the published work of Breman (2007) in South Africa, Adekanmbi and Ogundipe (2010) in the southwest Nigeria and most recently Adeonipekun and John (2011) and Adeonipekun (2012), there is no other aeropalynological work in this area to serve as a basis for aeropalynological study. The Breman (2007) study highlighted the fact that more samplers are needed, in more cities, to assist pollen allergy sufferers. Even the more local study of Adekanmbi and Ogundipe (2010) only identified most of the recovered palynomorphs to family level, thus not creating the needed basic data for comparative pollen analysis and allergy testing. The work of Adeonipekun and John (2011) was carried out on the dust deposited on a car bonnet over a month, resulting in non sufficient data for our goal, thus the sample used in the current study were collected from the air with an aerofloral sampler.

However, in the southeast Nigeria, works of Agwu and Osibe (1992), Agwu (2001), Agwu et al. (2004), Njokuocha and Osayi (2005) and Njokuocha (2006) have created a rich data base for comparison and research in aeropalynology.

The creation of a pollen calendar for every community, to give information out to the public about pollen occurrence in the air is much needed. Also, the determination of the weather parameters that may influence the pollen content/temporal variation in the air was assessed.

\section{Materials and methods}

\section{Study area and climate}

Shomolu Local Governments (Lat. 6.540833 and Long. $3.387222^{\circ}$, Figs. 1,2$)$ lie in the Ikeja Division of Lagos State, Nigeria. It has a population of about 402.673 million (2006 Census) and has a land area of $11.6 \mathrm{~km}^{2}$. In the North it shares boundary with Bariga Local Government and in South it shares boundaries with the Akoka communities. In the East the boundary is the major Ikorodu road from Fadeyi to Anthony and at the West, Abule-Ijesha. As in any urban area, the most significant aspects of the flora are the deterioration of the natural vegetation, an important component of ornamental plants and an increase of weeds. The flora is dominated by herbs of Alchornea, trees of Elaeis guineensis, Cocos nucifera, Mangifera indica and Terminalia catappa, grasses such as Panicum maximum, Axonopus compressus, Cynodon dactylon 
and Peninsetum purpureum and numerous plantations of vegetables. Most of the diverse flora is benefited from the University of Lagos, Akoka. It is also surrounded by the neighbouring Swamp vegetation of the Oworonshoki area, located further north of its boundary in Kosofe Local Government area. Major features in the area include an ultramodern hospital at Gbagada, three tertiary educational institutions, three ultra-modern markets, two food markets and an array of housing estates.

The region has a tropical wet and dry climate that borders a tropical monsoon climate. It experiences two rainy seasons, with the heaviest rains falling from April to July and a weaker rainy season in September to November. There is a brief relatively dry spell in August and a longer dry season from December to March, which is termed the harmattan period. This period is characterised by hot and dry weather with very low relative humidity. Monthly rainfall between May and July averages over $400 \mathrm{~mm}$, while in August and September it is down to $200 \mathrm{~mm}$ and in December as low as $25 \mathrm{~mm}$. The main dry season is accompanied by harmattan winds from Sahara Desert, which between December and early February can be quite strong. The highest maximum temperature ever recorded in was $37^{\circ} \mathrm{C}$ and the minimum $14^{\circ} \mathrm{C}$.

Many people from various parts of the State visit the city for its educational, business and social purposes. The present study will be useful for those who are sensitive to pollen allergy so that they can plan accordingly their visit and can escape from the incidence of allergy. The present paper deals with the pollen calendar of Shomolu Local Government with special reference to allergenic cases in hospitals, as well as meteorological parameters of the area.

\section{Pollen collection}

Three aerofloral samplers Gbenga-2, as constructed by Adeonipekun (2012), were used. The samplers were placed about $2 \mathrm{~m}$ above ground level (Dola et al., 2004) at three major regions in the Local Government: University of Lagos: Akoka, Bariga and Gbagada (Fig. 2). The samples were collected monthly from January 2013 to December 2013.

Standard palynological preparation technique was adopted where the sediment was acetolyzed Erdtman (1969). Twenty microlitres of the residue were dropped on a microslide and covered with a coverslip. Nail polish was used to seal the edges of the coverslip. Two slides were prepared and studied from each sampler residue (Adeonipekun and John, 2011). A monthly sum of the three locations was used to analyse the data for the local government areas.

\section{Collection of weather parameters and medical data for selected months}

The meteorological data was collected from the Nigerian Meteorological Agency, Nigeria. The parameters collected include: monthly mean temperature, monthly mean rainfall, monthly mean relative humidity and monthly mean wind speed.

The medical data on allergy cases where collected from Gbagada General Hospital. Records of number of pollinosis cases received monthly were collected. The following cases were analysed: rhinitis, wheezing cough and allergic conjunctivitis.

With the help of IBM SPSS computer programme, nonparametric statistical analysis by Spearman's rank correlation test was applied, to determine whether monthly pollen concentrations, meteorological parameters and medical data were significantly positively or negatively correlated.

\section{Results}

A total of 37 pollen types belonging to 30 families were identified in all locations. On average, pollen concentration increased towards late September and was the highest in late October. The highest values were recorded between October and December and the lowest between June and July. In January, the monthly pollen sum was relatively low and then continued to decrease gradually, reaching the minimum in July. Relative percentages of the pollen abundance are shown in Fig. 3. The most abundant pollen types include: Poaceae, Cyperaceae, Amaranthaceae, Alchornea cordifolia and Ludwigia sp. (Tab. 1 and Fig. 6). When analysing each separate taxa, the Poaceae pollen sums dominated from August to December, Amaranthaceae pollen dominated in January, February, March, April, June and July. Cyperaceae contribution was significant in June and July (Figs. 4 and 5).

From the value of the correlation coefficient, it was found that total pollen count was positively correlated with temperature and negatively correlated with rainfall, relative humidity and wind, but the values were not statistically significant. Furthermore, total pollen count showed a positive correlation to wheezing cough, but not statistically significant at $\mathrm{p}<0.05$ (Tab. 2). Statistically significant $(\mathrm{p}<0.05)$ negative correlations were recorded for Amaranthaceae and Alchornea cordifolia when compared with relative humidity. Ludwigia sp. and Cyperaceae pollen count showed significant positive correlation $(p<0.05)$ with wheezing cough, while none of the pollen recorded a positive correlation with allergic

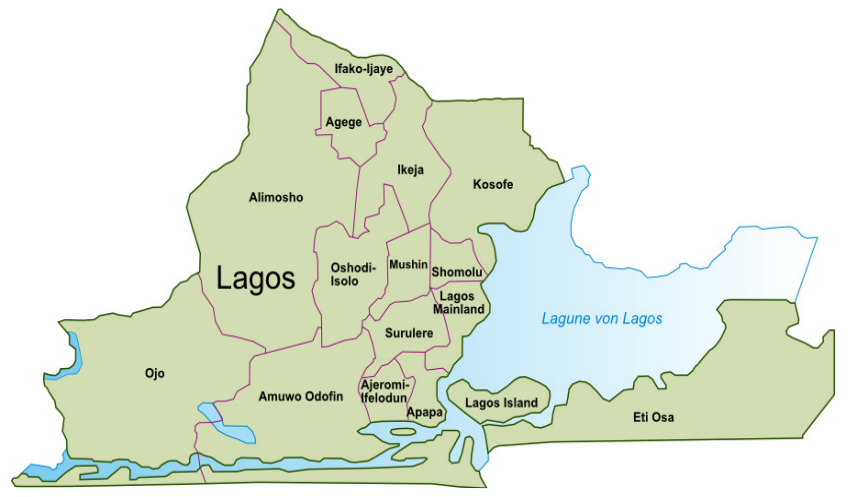

Fig. 1. Map of Lagos State showing sample area (

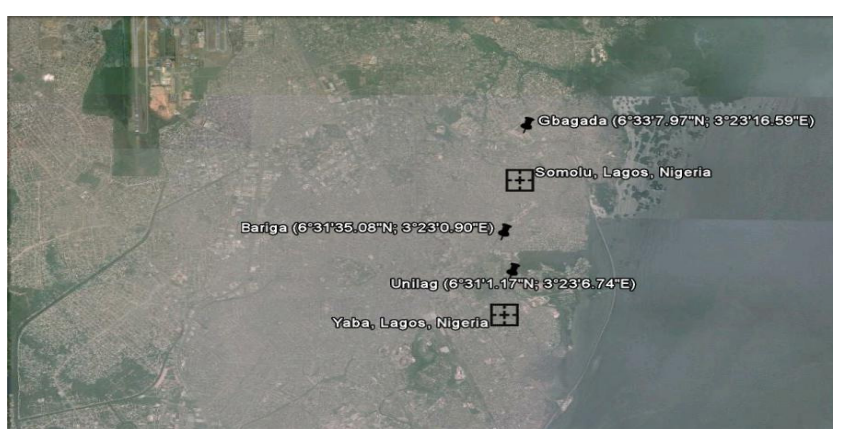

Fig. 2: Map of Lagos showing sample area and location of aeroflora samplers. G - Gbagada aerosampler; B - Bariga aerosampler; U - Unilag aerosampler 
430

Tab. 1. Airborne pollen of Shomolu Local Government

\begin{tabular}{|c|c|c|c|}
\hline Pollen & Families & Total & $\%$ \\
\hline Acanthaceae & Acanthaceae & 1 & 0.02 \\
\hline Asystasia gangetica & Acanthaceae & 19 & 0.43 \\
\hline Amaranthaceae & Amaranthaceae & 1236 & 28.14 \\
\hline Anacardiaceae & Anacardiaceae & 22 & 0.50 \\
\hline Elaeis guineensis & Arecaceae & 84 & 1.91 \\
\hline Raphia hookeri & Arecaceae & 70 & 1.59 \\
\hline Chromolaena odorata & Asteraceae & 4 & 0.09 \\
\hline Tridax procumbens & Asteraceae & 26 & 0.59 \\
\hline Avicennia germinans & Avicenniaceae & 8 & 0.18 \\
\hline Tabebuia rosea & Bignoniaceae & 1 & 0.02 \\
\hline Bombax buonopozense & Bombacaceae & 6 & 0.14 \\
\hline Senna sp. & Caesalpinaceae & 14 & 0.32 \\
\hline Terminalia catappa & Combretaceae & 68 & 1.55 \\
\hline Cyperaceae & Cyperaceae & 411 & 9.36 \\
\hline Acalypha sp. & Euphorbiaceae & 35 & 0.80 \\
\hline Alchornea cordifolia & Euphorbiaceae & 436 & 9.92 \\
\hline Euphorbia sp. & Euphorbiaceae & 15 & 0.34 \\
\hline Malvaceae & Malvaceae & 21 & 0.48 \\
\hline Albizia sp. & Mimosaceae & 19 & 0.43 \\
\hline Ficus sp. & Moraceae & 78 & 1.78 \\
\hline Musa sp. & Musaceae & 2 & 0.05 \\
\hline Psidium guajava & Myrtaceae & 1 & 0.02 \\
\hline Syzygium guineense & Myrtaceae & 12 & 0.27 \\
\hline Nymphaea sp. & Nymphaceae & 15 & 0.34 \\
\hline Ludwigia sp. & Onagraceae & 136 & 3.10 \\
\hline Pandanus candelabrum & Pandanaceae & 37 & 0.84 \\
\hline Dalbergia sp. & Papilionaceae & 4 & 0.09 \\
\hline Pterocarpus sp. & Papilionaceae & 7 & 0.16 \\
\hline Poaceae & Poaceae & 1443 & 32.85 \\
\hline Polygonum plebeium & Polygonaceae & 11 & 0.25 \\
\hline Rhizophora sp. & Rhizophoraceae & 6 & 0.14 \\
\hline Borreira sp. & Rubiaceae & 2 & 0.05 \\
\hline Canthium sp. & Rubiaceae & 43 & 0.98 \\
\hline Citrus sp. & Rutaceae & 20 & 0.46 \\
\hline Paullinia pinnata & Sapindaceae & 2 & 0.05 \\
\hline Sapotaceae & Sapotaceae & 5 & 0.11 \\
\hline Solanaceae & Solanaceae & 71 & 1.62 \\
\hline \multirow[t]{2}{*}{ Lantana sp. } & Verbanaceae & 2 & 0.05 \\
\hline & & 4393 & \\
\hline
\end{tabular}

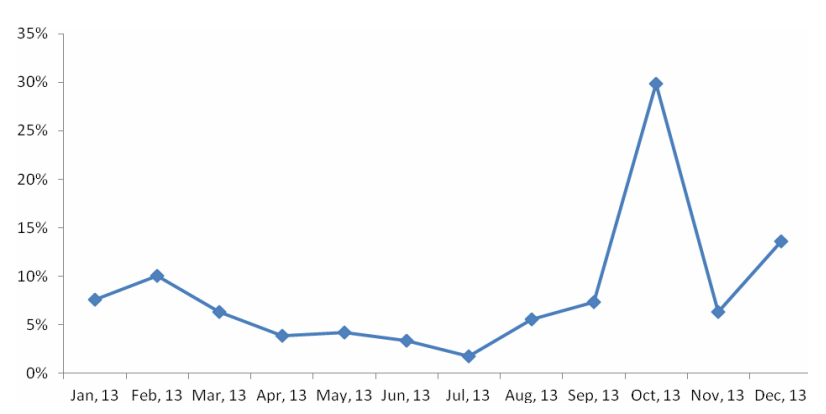

Fig. 3. Percentage pollen abundance in Shomolu Local Government

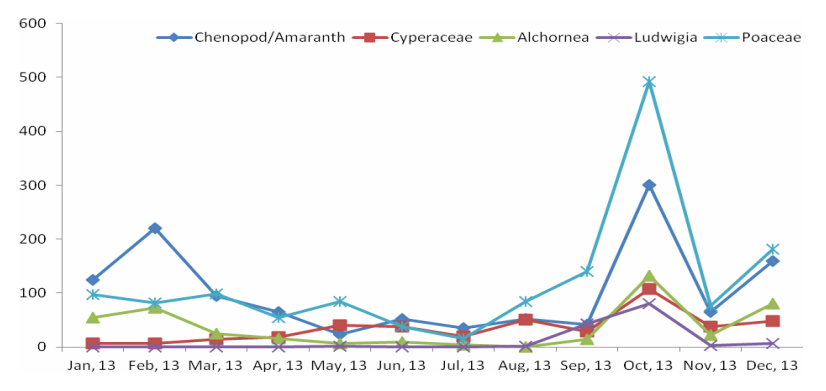

Fig. 4. Abundance of dominant pollen in Shomolu Local Government conjunctivitis. Ludwigia sp. and Cyperaceae both had positive correlations with asthma/rhinitis (Tab. 2).

\section{Discussion}

The total pollen and families' diversity (37 and 30 respectively) recorded in Shomolu Local Government was lower than that found in other sites in the country, like Nsukka (Njokuocha, 2006) and Ayetoro (Adeonipekun et al., in press). This difference is probably due to the massive urbanization of this region compared to the other sites. On average, two peaks of total pollen counts are recognizable in the area, the first being between late September to late December, mainly due to Poaceae, while the second is between January and March, due to full blooming of the Amaranthaceae and Alchornea taxa.

Seasonally, the pollen concentration was the highest during Harmattan (October to December; January to February), when $67.4 \%$ of the annual sum was recorded, and the lowest in the rainy season from June to July ( $5.21 \%$ of the annual sum). This could be as a result of the high blooming of plants under the harmattan weather. During the short dry break in August, $5.6 \%$ of the pollen sum occurred and in the brief pre-rainy season from March to May, $14.43 \%$ of the pollen sum was recorded. A high variety of pollen types was recorded, especially during the harmattan months. This could be as a result of the strong North-East Trade Winds that blow during that period, carrying both anemophilous and entomophilous pollen grains (Adeonipekun et al., in press).

Meteorological parameters like temperature, rainfall, relative humidity, wind direction and velocity are responsible for fluctuations in pollen concentration (Dola et al., 2004). Subiza et al. (1992) have shown that humidity and rainfall appear to be the predominant factors in determining the grass pollen season in Madrid, Spain. Rainfall and relative humidity usually yield negative correlations, since water droplets wash away pollen particles. Pollen sum show negative correlations with rainfall and relative humidity, and positive correlation with temperature, as found in Cartagena (Moreno-Grau et al., 1998; Angosto et al., 2005), Braga (Ribeiro et al., 2003) and Sydney (Stennet and Beggs, 2004). Unlike other studies (Ribeiro et al., 2003; Stennet and Beggs, 2004; Angosto et al., 2005), total pollen sum show negative correlations with wind speed. In Lagos State, the strong local winds from the coastal region have a dilution impact in pollen sum, as already found for Poaceae in Leon (Valencia-Barrera et al., 2001).

Analysing the five main taxa, correlations between pollen counts, rainfall and wind speed are positive for Ludwigia sp. and Poaceae pollen, and negative in the other three taxa. Cyperaceae and Ludwigia sp. also show negative correlation with temperature and positive correlation with relative humidity, as opposed to the three other taxa. The highly significant negative correlation of Alchornea cordifolia and Cyperaceae taxa with relative humidity further intensifies the suggestions of Moreno-Grau et al. (1998), Angosto et al. (2005), Ribeiro et al. (2003) and Stennet and Beggs, (2004) that relative humidity is the most statistically significant meteorological factor in aeropollen studies.

Significant positive correlation of Ludwigia sp. and Cyperaceae pollen with wheezing cough occurrence, suggests the high potency of these taxa in causing allergy. No studies 
431

have been conducted on Ludwigia sp. pollen and allergy that it can occur. However, Dola et al. (2004) has confirmed the allergenic potential of Cyperaceae pollen. With asthma/rhinitis occurrence, all pollen taxa show a negative correlation, except of Ludwigia sp. and Cyperaceae pollen which showed positive correlation, but was statistically insignificant. This further intensifies the need to subject these taxa pollen to allergenic tests. Neither the total pollen count nor dominant taxa showed relevant correlation with allergic conjunctivitis, suggesting a different causative allergen to the condition.

The commonest Poaceae species in the area include

Tab. 2. Correlation coefficients between pollen counts, meteorological parameters and medical data

\begin{tabular}{|c|c|c|c|c|c|c|c|}
\hline \multirow{2}{*}{ Pollen count } & \multicolumn{4}{|c|}{ Meteorological parameters } & \multicolumn{3}{|c|}{ Medical data } \\
\hline & $\mathrm{T}$ & $\mathrm{R}$ & R.H. & $\mathrm{W}$ & $\mathrm{AC}$ & $\mathrm{A} / \mathrm{R}$ & WC \\
\hline Total Pollen Count & .184 & -.116 & -.501 & -.201 & -.407 & -.085 & .053 \\
\hline Chenopod/Amaranth & .381 & -.406 & $-.699^{*}$ & -.244 & -.093 & -.206 & -.120 \\
\hline Cyperaceae & -.366 & -.130 & .489 & -.007 & -.250 & .161 & $.583^{*}$ \\
\hline Alchornea cordifolia & .147 & -.200 & $-.674^{*}$ & -.318 & -.018 & -.258 & -.067 \\
\hline Ludwigia sp. & -.315 & .112 & .300 & .023 & -.524 & .253 & $.592^{*}$ \\
\hline Poaceae & .041 & .016 & -.290 & .046 & -.322 & -.285 & .056 \\
\hline
\end{tabular}

*: Correlation is significant at the $\mathrm{p}=0.05$ level (2-tailed)

T, Monthly Mean Temperature $\left({ }^{\circ} \mathrm{C}\right) ; \mathrm{R}$, Monthly Mean Rainfall (mm); R.H., Monthly Mean Relative Humidity (\%); W, Monthly Mean Wind Speed (km/h); AC Allergic Conjunctivitis; A/R, Asthma/Rhinitis; WC, Wheezing Cough
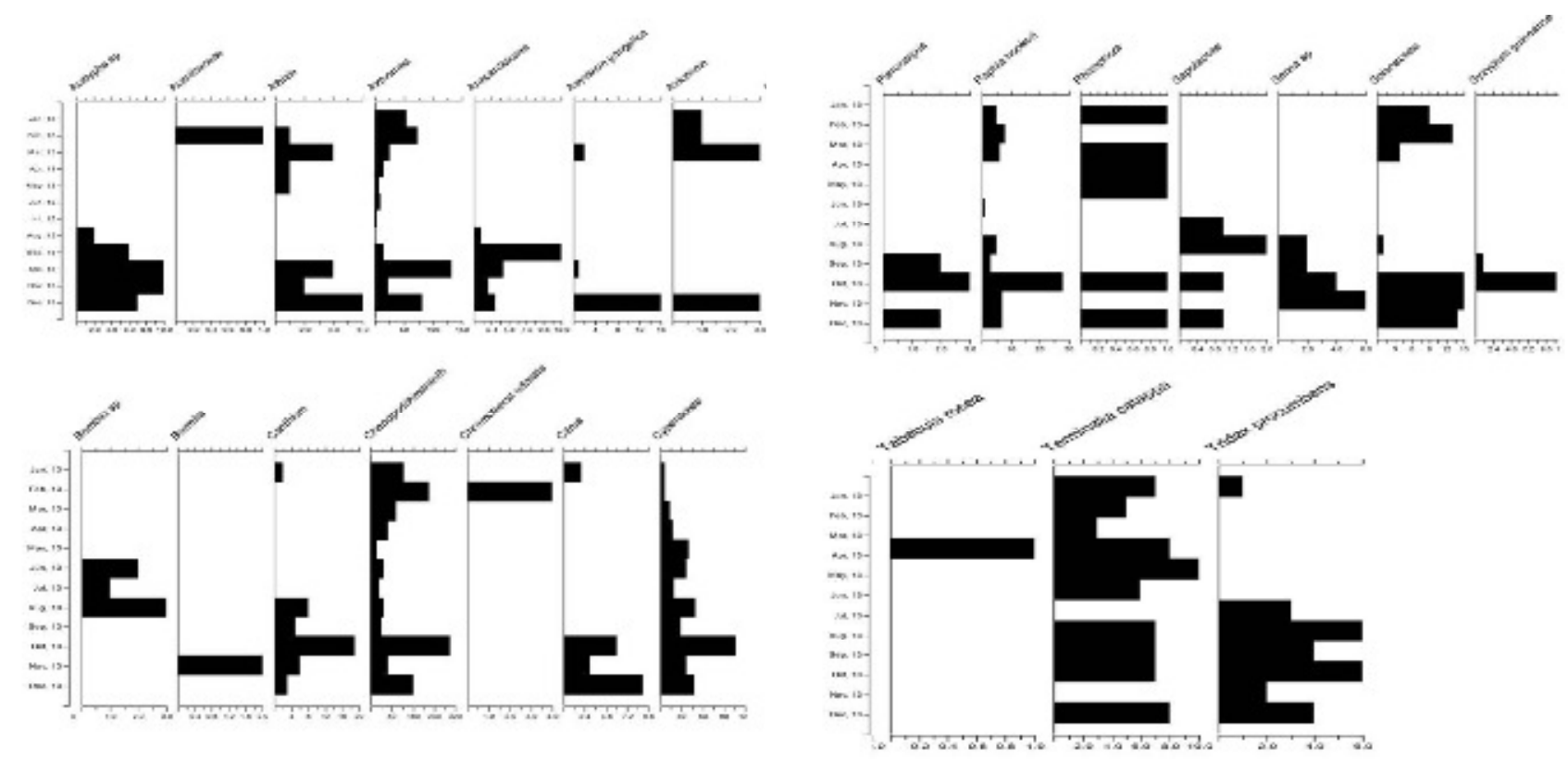

Fig. 5a. Pollen calendar

Fig. 5b. Pollen calendar

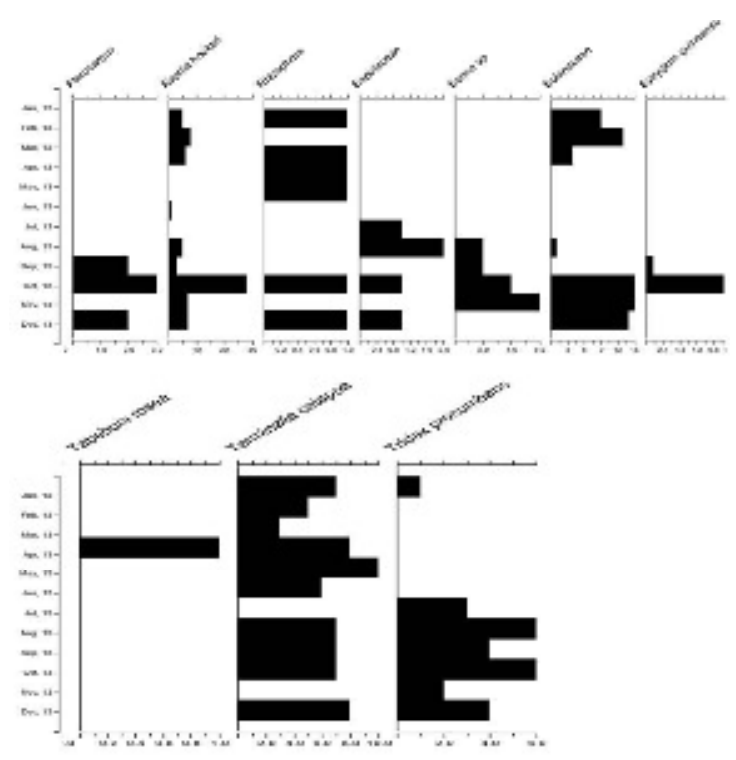

Fig. 5c. Pollen calendar 
432
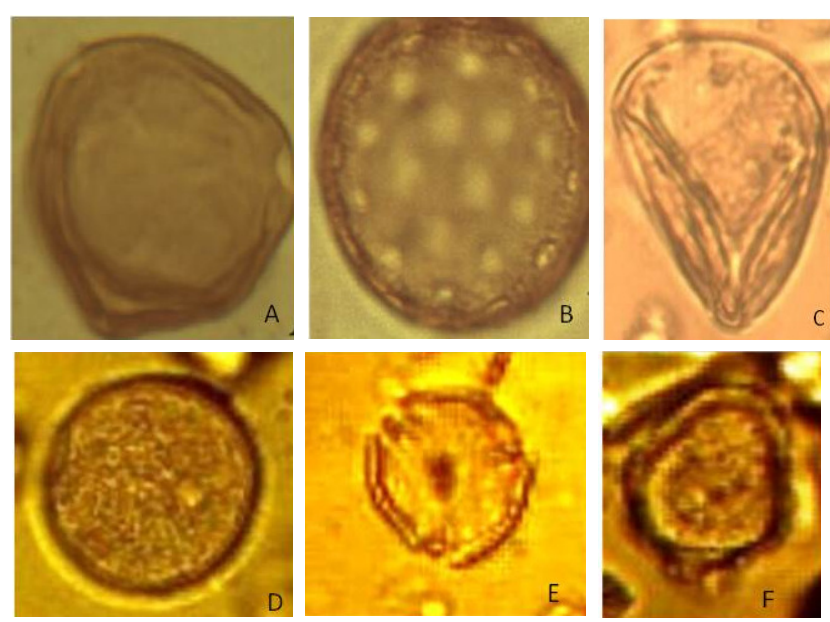

Fig. 6. Recovered palynomorphs: a. Ludwigia sp.; b. Amaranthaceae; c. Cynodon dactylon; d. Panicum maximum; e. Alchornea cordifolia; f. Cyperaceae

Panicum maximum and Cynodon dactylon, while Cyperaceae species in the area include Mariscus alternifolius and Cyperus rotundus. The commonest Amaranthaceae in the area is Amaranthus spinosus.

From the results, four pollen seasons can be identified (Figs. 5a-c):

1. The end of the Harmattan months and pre-rainy season which runs from January to May is the pollen season dominated by Amaranthaceae and Alchornea cordifolia.

2. A very low pollen count zone in June and July, dominated by Cyperaceae and Amaranthaceae pollen.

3. The combination of the short dry season and wet season from August to September dominated by Ludwigia sp., Poaceae, Cyperaceae and Amaranthaceae.

4. The high pollen season that runs from October to December, which represents the increase in Poaceae pollen count.

\section{Conclusion}

From allergological point of view, the most dangerous period for inhabitants of Shomolu occurs between October and September when the highest level of grass and weeds pollen grains were recorded. Pollen grains of Poaceae are important aeroallergens, however the role of other taxa, such as Ludwigia and Cyperaceae, in inducing allergy reactions in the region cannot be neglected. Our study showed that these plants might be responsible for the increasing incidents of wheezing/cough among allergy sufferers.

\section{Acknowledgments}

The authors would like to thank Records Office of the Nigerian Meteorological Agency, Nigeria and Gbagada General Hospital for all data supplied. Thanks to University of Lagos, Gbagada General Hospital and Bariga Local Council Development Area for allowing the use of their spaces as sampling sites.

\section{References}

Adekanmbi O, Ogundipe O (2010). Aeropalynological studies of the University of Lagos campus, Nigeria. Not Sci Biol 2(4):34-39.

Adeonipekun P, John M (2011). Palynological investigation of haze dust in Ayetoro-Itele Ota, Southwest Nigeria. J Ecol Nat Environm 3(14):455-460

Adeonipekun A (2012). Comparative aeropalynology of same months of two consecutive years in Ayetoro-Itele, Ota, SouthWest Nigeria.J Ecol Nat Environm 4(12):30-313.

Adler T (1985). Immunologic and clinical correlates of bronchial challenge responses to Bermuda grass pollen extract. J Allergy Clinical Immunol 86(5):62-65.

Agwu C (2001). A study of Niger Delta environment through airborne palynomorphs, Port Harcourt, Nigeria. Palaeoecol Africa 27:191-205.

Agwu C, Osibe E (1992). Airborne palynomorphs of Nsukka during the months of February - April, 1990. Nigerian J Bot 5:177-185.

Agwu C, Njokuacha R, Mezue O (2004). The study of airborne pollen and spores circulating at "Head Level" in Nsukka environment. Bio-Research 2(2):7-14.

Angosto J, Moreno-Grau S, Bayo J, Elvira-Rendueles B (2005). Multiple regression models for predicting total daily pollen concentration in Cartagena. Grana 44:108-114.

Berman D (2007). Pollen monitoring in South Africa. Curr Aller Clin Immunol 20(4):184187.

Dola B, Soma C, Kashinath B (2004). The occurrence and allergising potential of airborne pollen in West Bengal, India. Ann Agri Environm Med 11:45-52

Erdtman, G. (1969). Handbook of Palynology. Munksgaard, Copenhagen. p. 209.

Moreno-Grau S, Bayo J, Elvira-Rendueles B, Angosto J, Moreno J, Moreno-Clavel J (1998). Statistical evaluation of three years of pollen sampling in Cartagena, Spain. Grana 37:41-47.

Njokuocha R (2006). Airborne pollen grains in Nsukka, Nigeria. Grana 45(1):73-80.

Njokuocha R, Osayi E (2005). Airborne pollen and spore survey in relation to allergy and plant pathogens in Nsukka, Nigeria. BioResearch 3(1):77-84.

Ribeiro H, Cunha M, Abreu I (2003). Airborne pollen concentration in the region of Braga, Portugal, and its relationship with meteorological parameters. Aerobiologia 19:21-27.

Stennet PJ, Beggs PJ (2004). Pollen in the atmosphere of Sydney, Australia, and relationships with meteorological parameters. Grana 43:209-216.

Valencia-Barrera R, Comtois P, Fernandez-Gonzalez D (2001). Biogeography and bioclimatology in pollen forecasting. An example of grass in Leon (Spain) and Montreal (Canada). Grana 40:223-229. 